John Carroll University

Carroll Collected

History

1998

Schmutz, Schund and Sittliche Gefährdung: The Politics of

Children's Morality Legislation in Early Postwar Austria

Matthew P. Berg

Follow this and additional works at: https://collected.jcu.edu/hist-facpub

Part of the History Commons 


\title{
Schmutz, Schund and sittliche Gefährdung: The Politics of Children's Morality Legislation in Early Postwar Austria
}

\author{
Matthew Paul Berg \\ John Carroll University
}

Paternalistic measures to fashion the parameters of children's socialization and protect, or revise, the content of their education have been at the forefront of political and pedagogic concerns in Central Europe from as early as the Enlightenment. Particularly after the Ausgleich in Austria-Hungary (1867) and German unification (1871), liberal-minded and conservative theorists, politicians, and bureaucrats began to reconsider not only approaches to teaching the liberal arts or technical skills; they also turned their attention to areas deemed central to the socialization of minors. Paramount in the latter respect were the introduction of suitable civics instruction for future citizen-subjects and a renewed interest in how young people might use their free time most constructively in order to become law-abiding and productive members of society.

Since the 1980s, important contributions from a number of social historians and historical anthropologists have expanded our understanding of the history of children's socialization in Europe and, particularly, within Central Europe. ${ }^{1}$ This body of scholarship suggests that, since the 1860 s-1870s, authorities in Germany and Austria-Hungary became increasingly preoccupied with formal and extracurricular education - a concern related to a host of significant developments that introduced unprecedented social and political tensions. These included: the issue of centralized authority versus regional or ethnic particularism; the dislocation of rural village and small-town dwellers associated with accelerated industrialization and a more pronounced degree of class stratification; the gradual emergence of democratic participation; and, by the turn of the century, the formation of populist Christian-oriented and social democratic political organizations with agendas that either reinforced or challenged prevailing relationships of power. Such later nineteenth-century transformations brought with them new pedagogical challenges to the socialization of minors. Throughout the prolonged and tumultuous period of international and civil war, changes of regime and political radicalization, and the 
difficulties of reconstruction between World War I and the Wirtschaftswunder of the 1950 s and 1960 s, these challenges became even more pronounced. The "perils" of modernity - unemployment, dehumanization in the workplace and in crowded urban environments, the "cultural degradation" attributed to the consumption of mass-produced leisure goods and services-prompted protectionist responses on the part of pedagogues and politicians. Such reactions manifested themselves most markedly for reading material and other free-time activities. ${ }^{2}$

Late nineteenth- and twentieth-century initiatives against Schmutz- und Schundliteratur (pornographic and pulp literature) have attracted the attention of historians of Central Europe in recent years. In particular, the work of Margaret Steig, Georg Jäger, and Luke Springman has offered important insights into the role played by pedagogic and political authorities in the enactment of legislative "safeguards," derived from the principle of paternalistic censorship. ${ }^{3}$ The state's role as guardian of long-established moral values, exercised by a host of legislative, executive, and pedagogic agents is emphasized by these scholars. Their work demonstrates that the dominant discourse throughout the larger part of the twentieth century has been characterized by traditional notions of protection from and control over "pernicious influences" associated with modernity, with the assumption that the absence of lowbrow, unsavory, and/or seductive forms of leisure would prompt the return of young people's attention to Church-sanctioned or community-oriented activities and organizations.

Ignored in both the late nineteenth- and twentieth-century discourse and current scholars' examinations of extracurricular socialization is a consideration of how initiatives to guide minors' leisure time activities deemed undesirable could be redirected towards forms of activity that might reshape the values -indeed, the identity — of young people as a necessary step towards refashioning society. ${ }^{4}$ This essay advances one particularly significant case study in the extra-curricular socialization of young people during the initial years of the Second Austrian Republic: a bipartisan, yet contentious effort on the part of the Sozialistische Partei Österreichs (Austrian Socialist Party, hereafter SPÖ) and its Catholic-conservative senior coalition partner, the Österreichische Volkspartei (Austrian People's Party, hereafter, ÖVP) to bar the access of minors to Schmutz and Schund during the late 1940s and 1950s.

Close cooperation between the ÖVP-SPÖ coalition partners in the federal government (and frequently at the province and local levels) combined with the "social partnership" of ÖVP-dominated farmers', industrialists', and shopkeepers' associations and the overwhelmingly social democratic Austrian Trade Union Federation and Chamber of Labor promoted a high degree of consensus between these two camps after 1945. Indeed, cooperation provided the fundamental stability that enabled the reconstruction of economic and social life, ${ }^{5}$ allowed for the fashioning of a common sense of purpose during four power occupation between 1945-1955, and contributed to the ability to thwart a communist coup in the Soviet 
occupation zones of eastern Austria, even as democracy in Poland, Hungary, and Czechoslovakia were subverted through such intrigues. ${ }^{6}$ The bitter, at times violent divisiveness in interwar Austria, which had pitted an authoritarian form of Catholicconservativism against a rhetorically militant, socially progressive, yet paternalistic social democratic vision for Austria's future, rarely surfaced after 1945. When it did, it was limited generally to election years, during which each camp excoriated the other for past misdeeds - only to return to the bargaining table once a new coalition agreement was reached. ${ }^{7}$ This pattern played itself out time and again, as both parties sought to remind their constituency and persuade the undecided of the skeletons in the other's closet; afterwards, such barbs were overlooked in the interests of solidarity and repression of a Nazi past for which neither the social democratic nor the Catholic-conservative traditions were wholly free from responsibility. ${ }^{8}$

It would be a mistake to assume, however, that differences between the SPÖ and the ÖVP were so insignificant that debate over the shape of Austria's future was merely the political equivalent of professional wrestling -i.e., that differences could be reduced to ugly, exaggerated media events, limited to electoral contests or the occasional commemoration of a politically loaded event from the short-lived interwar republic. Cultural policy and closely related elements of social policy represented the only sites at which party and interest group leaders were unable (or perhaps were unwilling) to contain the expression of fundamental Lager-based differences voiced by cultural organizations in both parties - organizations that labored primarily at the margins of a largely employment and economic growthoriented coalition agenda during the reconstruction years. By highlighting those areas where polarized perspectives could not be easily reconciled-e.g., a new school law, Church-state relations, marriage and family policy, ${ }^{9}$ and, as I argue here morality legislation for the protection of children - the competing value systems and the stakes perceived as crucial for determining the shape of Austria's future become apparent. Thus, this article focuses upon the terms of the debate concerning the protection of minors' morals and alternatives to Schmutz and Schund, rather than occupying itself principally with an assessment of the effectiveness of such legislation.

\section{Attitudes Toward Schmutz- und Schundliteratur Before 1945}

Attempts to alert the public to the dangers of Schmutz-und Schundliteratur did not originate with the Second Republic initiative. The issue had been championed by the Roman Catholic Church, bourgeois parties, social democratic organizations, and even the National Socialists during the years prior to 1945. Examination of this campaign and its significance for childhood socialization after the Second Republic's foundation requires consideration of a host of pedagogical, political, and constitutional issues. Foremost among them is the question of moral protectionism to safeguard young people against stimuli which, experts feared, might work against the 
inculcation of values central to the creation of an Austrian identity, and, for social democrats, the creation of leisure time options considered culturally rewarding and socially valuable. Directly related to this concern, moreover, were the necessities of addressing social problems credited with contributing to the moral decline of young people, such as housing shortages and overcrowding of apartments, or the uncertain prospects for future unemployment during the late 1940s and early 1950s; few outlets for the constructive use of free time; ${ }^{10}$ the legal ramifications of limiting freedom of the press; and the conflict between federal legislative and executive authorities on the one hand, and the powers provincial authorities sought to preserve on the other. The debate concerning the initiative against Schmutz- und Schundliteratur demonstrates how the activity of the legislative and executive bureaucracies overshadowed and, perhaps, smothered the initial citizenship-oriented, pedagogical, and moral concerns of those who championed the campaign.

Leisure-time options advanced by the SPÖ to counter the appeal of Schmutz and Schund publications manifested the party's commitment to the formation of a new kind of citizen in the wake of some thirty years of domestic and international strife. This conception of a new, republican Austrian was modeled very closely on the sort of neue Menschen whom the social democratic movement sought to cultivate through a variety of cultural initiatives during the $1919-1934$ period. ${ }^{11}$ The social democratic camp revised the nature of its opposition to Schmutz and Schund significantly after 1945, however, expanding its focus of concern from a traditional almost exclusively working-class orientation to one that encompassed society at large. By broadening its pedagogical focus, the SPÖ sought to emphasize that social democratic values and their institutionalization in a progressive social order befitted the life circumstances of all working Austrians-not merely the traditional, primarily blue-collar constituency. Rather than conceive of the role of state and society as moral guardians of youth, thereby advancing their campaign against Schmutz-und Schundliteratur as a largely preventative endeavor, Social Democrats combined a traditional emphasis upon providing constructive alternatives to these publications with an insistence that the campaign should not provide an occasion for the expansion of censorship.

The standard social democratic characterization of Kitsch-und Schunditeratur during the First Republic described this danger as a broad corpus of published material with an intoxicating effect, in which flight from reality led working-class people to struggle against their "better nature" instead of against their Catholicconservative class enemy. ${ }^{12}$ Novels that reinforced bourgeois moral codes, as well as violent mystery and adventure stories received criticism from directors of special "workers' libraries" established in Vienna and in other working-class strongholds, such as Linz. Party-endorsed works of fiction and social science were showcased in these institutions, in tandem with the creation of adult education programs (including literature discussion groups), as part of an intensive program to nurture the rank and file toward understanding the social and historical realities of the 
circumstances under which they lived. Participation in many party educational programs was rather strong, particularly in Vienna, yet recent research has indicated that workers' libraries tended to lend fiction titles far more frequently than historical, sociological, or philosophical volumes. ${ }^{13}$

\section{The Campaign against Schmutz- und Schundliteratur in the Second Republic}

After 1945, the same genres resurfaced that Social Democrats had abhorred during the interwar years: violent westerns and adventure novels (chiefly, but not exclusively authored by Karl May and Zane Grey), criminal stories depicting grisly murders or the sinister abduction of young women, mass-produced gothic romances, and pornography. Many of these works were reprinted within Austria or introduced from America and England via West Germany. Challenges regarded as still more pernicious manifested themselves in the form of inexpensive and colorful comic books (whose themes of fantasy and violence tended to appeal to children of all ages), as well as in the publication of pornographic literature and picture books.

By the late 1940s, the SPÖ joined a chorus of voices that came to include the other political parties, the Church, teachers, parents' groups, and psychologists, in calling upon the government to create a commission that would recommend lists of pedagogically unobjectionable books, films, records, and theater performances. ${ }^{14}$ The proponents of this panel envisioned it as a body of pedagogues, psychologists, physicians, legal scholars, artists, writers, film industry representatives, and clergymen who would serve as consultants to the government both during and after the enactment of comprehensive legislation to protect Austria's youth from a new onslaught of Schmutz and Schund. Those organizations which designated as potential participants in an overseeing commission agreed upon little else than the need for such a body, however. An insurmountable divide separated those who advanced the future-oriented social democratic conceptions and those who championed the proscriptive measures advocated by Catholic-conservatives. The latter approach to childhood socialization for a new Austria were oriented decidedly toward the past; values pressed by the ÖVP had their origins in the Habsburg Monarchy-i.e., traditional religiosity, control over the sexuality of young people by teaching adherence to a strict catholic moral code, and the advocacy of selfless courage and gallantry in the interests of society as a whole.

The impetus for a legal solution was undertaken by the government itself, with advice from the sort of heterogeneous panel of experts called for by the groups noted above. Commissioned by the Ministerrat, a group of officials from the chancellery, the Interior Ministry, and the Ministries of Justice, Social Administration, Trade and Reconstruction, and Education began a careful examination into both extant morality legislation and measures initiated within several Austrian provinces between the summer of 1947 and the spring of 1948. The question of how extensive a character federal legislation might assume immediately raised the Bund vs. Land competence question when officials examined a Jugendschutzgesetz proposed by 
the Salzburg Landtag that suggested far-reaching control over minors. Proposed restrictions included: no admittance to bars, nightclubs and cabarets; no hotel or inn stays for children under eighteen unless accompanied by an adult; entrance to restaurants denied to children under sixteen without an adult (and permitted only until 9:00 PM even with adult supervision); attendance at public theatrical performances for children younger than fourteen only when accompanied by a teacher or responsible adult, unless the performance was staged specifically for children; participation in public dances limited to minors between ages fourteen and seventeen, only allowed until 11:00 PM, and then only with chaperones present. ${ }^{15}$ The Salzburg draft also called for keeping youths from arcades, bowling halls, and shooting ranges, reflecting a concern for the maintenance of public peace, order, and security technically under the purview of the federal police. ${ }^{16}$ Faced with additional outlines drafted by the provincial governments of Vorarlberg and Tyrol that raised similar confusion with respect to Bund-Land jurisdictions, constitutional law experts associated with the chancellery deemed it necessary to create a contemporary, uniform, federal legal basis for the protection of minors against Schmutz and Schund, whether in printed form or in the broader entertainment sector. This decision found favorable responses in the federal ministries, the Church, among the political parties, within parent, teacher, and youth organizations, and ultimately even in the provincial governments. ${ }^{17}$

The basis upon which the government sought to build a legislative bulwark against Schmutz and Schund was described carefully by Justice Minister Josef Gerö in a communiqué to Austrian state attorneys: "The healthy physical and psychological development of young people is once again being endangered by countless pieces of writing and pictorial representations, which are either lewd, i.e., characterized by their [tendency to] elicit sexual excitement, or-without leading directly to pleasure in the sexually obscene [sense] - they are objectively designed to over-excite or mislead the sexual impulses of young people."18 Until the point at which a new law would come into effect, Austrian state attorneys were directed, as authorized by the Strafgesetznovelle of 20 December 1929 (BGB1. Nr. 440), to take action against anyone who knowingly

(1) offered publications, illustrations, or other representations for sale to a person under 16 years of age that were "lewd or designed to over-excite or misdirect the sexual feelings of the youth"; (2) displayed, posted or otherwise disseminated such a publication or representation in such a manner that through [its] offensive content it was made accessible to a larger circle of people under 16 years of age; or (3) showed a motion picture of the above-mentioned variety to a person under 16 years of age for payment. ${ }^{19}$

While these measures were welcomed generally as positive steps towards limiting children's access to Schmutz and Schund, critics complained that they 
failed to suggest effective means to preclude the appeal of such material. The SPÖ pedagogic expert Leopold Zechner, in his capacity as President of the Viennese Municipal School Council, welcomed the government's movement on the initiative, but registered the opinion of the leaders of the Viennese parents' council to Gerö's proposed legal measures to combat Schmutz and Schund. The position of the Kinderfreunde (a kind of SPÖ adult-membership organization for the mentoring of children) and the social democratic-dominated Viennese parents' council took the form of a list that included several explicit demands:

- [A] ban on these types of products will not suffice alone, but in their place [pedagogically] valuable products must be promoted. In this connection [...] centers for adult continuing education, in [ostensibly fulfilling] one of the cultural tasks of these institutions by showing sensationalist films according to prevailing tastes and the public's desires, do not make corresponding concessions, and this does not bode well.

- It has become public knowledge that in addition to culturally repulsive wrestling and boxing matches, even concessions for holding bull fights have recently been sought from a central, representative cultural institute. The parents request that these concessions be renounced for reasons of good taste and with consideration for the brutalization of [the sensibilities of] young people. $^{20}$

News of reactions in Vienna, characterized by a marked concern with nonviolent and meritorious cultural options, rather than the government experts' preoccupation with preventing children's access to pornography, precipitated a rethinking of "morality legislation" among both federal and provincial authorities. A somewhat different proposal from those proposed by either the federal government or SPÖ-oriented groups in the capital was advanced in an editorial from 3 June 1948 in the Volksbote, a conservative Tyrolean newspaper. The author advocated a cultural-political tax on films and publications of a "less-valuable" nature, as was the practice in Switzerland; the revenues from the tax could be employed to promote "quality" entertainment. ${ }^{21}$ The Provincial School Council for Tyrol would assemble a commission, the editorial envisioned, to determine which publications would be subject to the tax, and payment would be exacted from the publishing house, if it were located in Tyrol-otherwise the retailer would be subject to the tax. ${ }^{22}$ The Volksbote scheme overlooked several important considerations, however, particularly if applied at the federal level. If the Bund passed legislation to combat Schmutz and Schund in a form acceptable to parents, pedagogues, and politicians, the tax would not raise revenue if the literature and film products concerned were outlawed. Assuming that these products were as popular as Zechner alleged, and that a law banning them was not created, publishers and film makers would have been 
undeterred by a "sin" tax; the cost would be calculated into manufacturing costs and reflected in an increased retail price which would anger consumers, but most likely not dissuade them. Finally, the Volksbote did not entertain the overriding concern that had occupied participants at the Viennese parents' council conferencenamely how one might encourage pedagogically sound reading and visual entertainment for children. The Tyrolean Landtag acted to draft legislation on the basis of the Volksbote proposal, much to the dismay of those in the publishing or newspaper and magazine retail sectors who complained to the federal government that the measure enacted in Tyrol threatened to undermine constitutionally guaranteed press freedoms. ${ }^{23}$

A draft law proposed by the Education Ministry in March 1949 attempted to address the problem of Schmutz and Schund by synthesizing the preventative measures proffered in the outline crafted by the Salzburg Landtag one year earlier with the constructive suggestions raised by the SPÖ through Zechner and the Viennese parents' council. ${ }^{24}$ A great deal of confusion remained regarding the division between Bund and Land authority, however. The outline called for the creation of a commission to review films for their suitability for minors-yet regulation of cinemas still fell within the purview of the provinces, while police supervision of arcades and similar establishments remained a federal responsibility. ${ }^{25}$ To address this discrepancy, Chancellor Leopold Figl rallied his ÖVP ministers around the notion of entrusting federal authorities with the charge for enforcing the law. A law granting the responsibility for reviewing publications and films to pedagogues and psychologists in the provinces, instead of those at the federal level, would have given executive authority to SPÖ-led governments in Vienna and Carinthia, rather confining social democratic influence to that of junior partner in the ÖVP-led coalition government. ${ }^{26}$ On the other hand, central authority over the enforcement of Schmutz and Schund controls permitted the SPÖ to share in the crafting of the legislation from a position of greater strength than it would have had in overwhelmingly ÖVP-dominated Länder such as Tyrol, Upper Austria, or Vorarlberg. In fact, the ÖVP-led provincial governments of Tyrol and Burgenland, supported strongly by the Church, pushed for a decentralized law that would have prevented a central, Vienna-based organization-one in which the SPÖ and ostensibly more "progressive, cosmopolitan influences" would be strongly represented-from determining what should be designated as Schmutz or Schund. ${ }^{27}$

The Education Ministry proposal generated a great deal of discussion, as well as pointed criticism, within the circles of both the government and interest group associations. How might the fundamental rights of freedom of expression and freedom of the press be affected by a law against Schmutz and Schund? The Association of Democratic Authors and Journalists for Styria objected to outlawing material designated as "lewd" and suggested the passage be reworded to read "a publication or image is to be considered as such if it was authored with the intention of provoking sexual excitement."28 In emphasizing measures against Schmutz, 
however, the category of Schund could not be ignored, cautioned the Interest Association for Catholic Book Trade; works which described acts of violence and murder "with the greatest [degree] of crudeness" could not be under emphasized. ${ }^{29}$ It remained unclear, though, what the criteria would be for designating material as obscene on the one hand, and as idle fantasy or rubbish on the other. Justice Ministry officials feared that in the former instance, classic works of literature that openly addressed sexual relations or even scientific works on sexual pathology might be subsumed under the category of Schmutz and Schund. The commission empowered to decide which works would be placed on the banned list might issue decisions that traduced significant authors and works. ${ }^{30}$ Skeptics and critics in a variety of organizations were troubled as well by the question of who would have the authority to form the commission entrusted with reviewing questionable publications and films. Opinion from SPÖ circles challenged the proposal that the Catholicconservative led Education Ministry would appoint the members of the commission. In order to anchor the commission's competency in democratic practice and to preserve its work from bureaucratic influences less accountable to the public, the social democratic interests suggested, to no avail, that its president and members should be chosen by parliament. ${ }^{31}$

According to the draft of the law against Schmutz and Schund advanced by the government, individuals or firms producing publications, pictures, audio prints, films, or theater performances falling under the competence of the law, and those who distributed these products to children under eighteen years of age would have been subjected to a fine of ÖS 3,000 or four weeks imprisonment. ${ }^{32}$ Yet what if parents, exercising their own pedagogical judgment, urged a banned publication upon their children with the conviction that the material was not pernicious, but beneficial? The Justice Ministry's position was that the law should not intervene so deeply into the educational prerogative of parents. ${ }^{33}$ Moreover, many minors between the ages of sixteen and eighteen led an independent existence as apprentices and no longer lived under parental jurisdiction, and a number of young women married at this age. The Justice Ministry opinion argued that application of a law against Schmutz and Schund to people falling into these categories would be perceived as ridiculous by the population, and, especially in the case of married minors, the law would be unenforceable. ${ }^{34}$

Faced with this impasse, the committee of governmental ministers who entrusted the Education Ministry with the task of drafting an outline commissioned the Justice Ministry to find a compromise. ${ }^{35}$ While the SPÖ did not oppose the creation of measures intended to protect Austria's youth against Schmutz and Schund, the party was concerned about the direction taken by the initial Education Ministry outline and the terms of the Justice Ministry revision. Preservation of Austrian civil liberties was the primary social democratic concern on the eve of parliamentary debate over the Justice Ministry draft. "The position of the Socialists on the battle against Schmutz and Schund which has occupied the public recently can 
be summarized in one sentence," the theoretician Oskar Pollak suggested in the SPÖ monthly Die Zukunft. "Protection of young people-yes; censorship and ministerial supervision of the sexual life of citizens-no." ${ }^{36}$

Two issues were at stake, as far as Pollak was concerned. First, the "clerical press" misrepresented the SPÖ's advocacy of sexual education and birth control as sexual libertinism, and stressed the importance of checking the social consequences of uninformed sexuality. ${ }^{37}$ Abstinence was, indeed, an option for teenagers, Pollak acknowledged, but one could not legislate it or punish the natural sexual curiosity of young people during their pubescence. Second, Pollak warned that, if passed, a law similar to the draft proposed in 1949 by the Education Ministry might set a precedent that would lead to the progressive erosion of the democratic foundation of Austrian society.

Hurdes' outline of a law against Schmutz and Schund, which sought to place all authority for its destruction in the Ministry of Education has been done away with; through the introduction of a censorship commission it would have infringed upon the freedom of the press and the Austrian constitution, through its procedural determinations it would have encroached on the authority of the courts and the provinces. It would have indirectly made the clerical Herr Ministerialrat $X$ of the commission assembled by the clerical Ministry of Education into a permanent expert on Schmutz and Schund, i.e., into the lord of literature and film. ${ }^{38}$

According to Pollak, the Justice Ministry revisions also fell short of expectations. Gerö did not seem to grasp the delicate and purely subjective nature of determining at what point descriptions or actions in literature or film might sexually stimulate a child. While at first glance wholesale censorship of such material appeared the surest corrective, such a sweeping solution still threatened to infringe upon press freedoms. "One will not be able to define and regulate an admissible level of sexual excitement, either in normal nor in morally disrupted times," Pollak admonished. "There is hardly a norm for morality, [and] decidedly no norm for sensuality which the authorities could decree and whose observance they could enforce." ${ }^{39}$

Pollak concluded that a thorough reform of legislation punishing certain forms of sexuality was fundamentally necessary before one could begin to talk about measures to combat Schmutz and Schund. This would include, he suggested, abolishing medieval vestiges in the Austrian legal code, such as the criminal punishment of homosexuality. Society would be better served by inserting a sentence at the forefront of a modern sexual criminal law stipulating that it would be permissible for mature, consenting, healthy people to seek satisfaction of sexual desire in any fashion they please, as long as this occurs without injury to the rights of others and without public sensation. [Such a law would] protect the freedom of the will, the health of the body, and the physical and moral development of young 
people. That would mean: [that which is] punishable is every limitation of free will, thus violence, exploitation of physical or psychological defenselessness, abuse of relationships based on dependency, especially of a familial, economic, or social nature. ... A clear understanding of ideals worth protecting and a clear wording of the law should guarantee that this is the path to physical as well as moral cleanliness and health, [and] thus the path to overcoming Schmutz and Schund..$^{40}$ Pollak's argument demonstrates the social democratic debt to classical liberalism, as well as the distinctly democratic socialist commitment to social justice. Its rejection of patriarchy - oft-stated by the SPÖ, but manifested far less frequently in practice, ${ }^{41}$ stands in marked contrast to ÖVP parliamentarians' demands that tradition be cultivated in dress, music, ritual, and social relationships.

The SPÖ had not shown enthusiasm for the Catholic-conservative Schmutz and Schund initiative because social democrats were sexual libertines, but because they had absolutely no desire to assume co-responsibility for what they dismissed as the peevish, hypocritical work of an ÖVP-dominated "morality" commission. ${ }^{42}$ As SPÖ parliamentary representatives explained in the debates over the Justice Ministry draft in March 1950, if the party were to support legislation against Schmutz and Schund, publishers and production companies would have to be targeted for punitive measures, not merely the simple kiosk salesperson or shopkeeper. Furthermore, by increasing the funding and the emphasis upon youth theater ensembles and heightened attention to music and art history, they maintained that children could be weaned away from comic books, pulp adventure novels, criminal stories, and war tales toward more edifying genres. ${ }^{43}$

Peter Strasser, a social democratic parliamentarian and leader of the Sozialistische Jugend, expressed concern for the consequences of the Schmutz and Schund proposal, given the near hysteria which pervaded the issue. Strasser and the communist deputy Ernst Fischer cited the case of the Tyrolean authorities' confiscation of "Schleichendes Gift," an educational film on sexually transmitted diseases, as a telling example of how even pedagogically significant projects might be censored by the proposed legislation. ${ }^{44}$ Moreover, Strasser continued, if the ÖVP's overriding concern was to prevent children from obtaining pornographic literature, the proposed legislation ignored the problem of violent films and publications which, he charged, were at the heart of the most pressing childhood pedagogical and developmental challenges. In support of his point, Strasser calculated that in one Karl May novel of 2,612 pages, 2,293 people were killedincluding 1,600 shot, 240 scalped, 219 poisoned by poison or gas, 130 stabbed, 61 beaten to death bare-handed, 16 drowned, 8 dead of starvation, 4 hanged, and 3 eaten alive by crocodiles. ${ }^{45}$ By contrast, he concluded, the ÖVP's emphasis on pornography as the overriding threat to the moral health of young people seemed a tremendous exaggeration; Schmutzliteratur appeared almost exclusively in the form of very expensive little brochures, and was too difficult for children to afford in quantities great enough to warrant the concern reflected in the proposed 
legislation. ${ }^{46}$ Karl May's works were not difficult nor too expensive for children to acquire, and the works of Zane Grey and other English-language violent adventure authors and comic books became increasingly accessible by the early 1950 s.

SPÖ criticisms notwithstanding, the "Federal Law Concerning the Elimination of Lewd Publications and the Protection of Youth against Ethical Endangerment" was ratified by parliament on 31 March 1950 through a combination of ÖVP, rightwing, and -in the interest of coalition solidarity - only tepid SPÖ support. It was approved by the occupation authorities, who assumed a rather disinterested air with respect to the entire debate, on 21 July $1951 .{ }^{47}$ Activists within the SPÖ had hoped to address these challenges to childhood socialization in a manner that they considered constructive and comprehensive, and regretted that the law did little more than indulge Austrian philistinism its preoccupation with pornography ${ }^{48}$ It may very well have been the case, though, that the frustration of social democratic critics in this particular clash in the larger, if usually sublimated, war over cultural policy was the result of the SPÖ elite's relative lack of interest in the campaign. Cultural policy in this instance may have been sacrificed to political expediency when, one must surmise, that Socialist leaders decided that the issue did not eclipse more tangible issues in importance-e.g., wages and prices, unemployment, and housing.

Even after ratification of the law, however, SPÖ activists in the Kinderfreunde, Rote Falken (the SPÖ children's organization), and the Sozialistische Jugend continued to combat the appearance of publications that romanticized war, rowdyism, and murder. The SPÖ parlimentary fraction leadership clearly regarded the matter important enough to be brought to the floor in debate, and the SPÖ Parteivorstand considered it of sufficient merit to devote time to it through radio addresses-if only to maintain a steady degree of pressure on the Catholic-conservative camp to express its clerical, bourgeois values. For example, in a passionate radio transmission Anton Parfuss admonished Austrians not to forget that "these books direct the drive for adventure and daring of our boys into negative forms. They inflame the fantasy of our children to hate, to brutality, for the most gruesome, the strongest, and the most perfidious are victors and rate as heroes in these trashy publications." ${ }^{49}$ For Parfuss and other social democratic education experts, the central issue where Schmutz and Schund were concerned was the free development of the child's personality - not the adult's sense of propriety. Richard Bamberger, whose association with the Sozialistische Bildungszentrale and position as Director of the Youth Book Club lent him an authoritative voice as an SPÖ pedagogue and theoretician, observed dryly that the current generation of Austrian adults-who had experienced two world wars, three political revolutions and the circumstances of black-market economy-had little reason to be self-righteous with respect to their moral fabric and political maturity. ${ }^{50}$ The real problem was not that children would find out about sex, as the ÖVP believed, but that they might very well grow up never having had a fruitful relationship with both classic and progressive literature. ${ }^{51}$ Bamberger appealed for an initiative cutting across party lines to alert 
both parents and children to this danger, but his plea stimulated little enthusiasm outside of the SPÖ and became a leitmotif only within the Rote Falken, and the Sozialistische Jugend..$^{52}$

The tremendous influx of comic books, literature, and films from abroad glorifying violence and suggesting/depicting sex in the second half of the 1950s prompted invigorated attacks upon $S$ chund from the left, and against Schmutz from the right. Estimates that approximately 20 million comic books had been sold in Austria during 1954 prompted an outcry from the SPÖ to ban the import of comic books altogether. ${ }^{53}$ The effect of these publications on Austrian children was said to be disturbing. Reports of the impact of Schund on children abounded, such as that of a mother of a seven-year-old Viennese child who complained to her son's teacher that the boy could not sleep without a kitchen knife under his blanket to ward off the one-eyed monster which figured so prominently in his favorite comic book. ${ }^{54} \mathrm{By}$ 1955, the historican Reinhold Wagnleitner points out, some fifty-three comic series could be purchased in Austria, the majority of which were introduced from West Germany. ${ }^{55}$ This point offers additional insight into Bamberger's concern that primitive illustrations and the minimalization of texts composed in poor German had the potential to place stumbling blocks before the cultural maturation of young Austrians. ${ }^{56}$ Bamberger's Youth Book Club, with its sizable organization of 160,000 members, figured prominently in efforts to promote quality literature for children, and the conservative-led Education Ministry joined in the effort by offering an annual prize of ÖS 10,000 for the best new work in children's literature. ${ }^{57}$ Even though they acknowledged the Education Ministry's good intentions, SPÖ activists continued to argue that social policy initiatives, in conjunction with import restrictions and revitalized educational efforts, remained the keys to successfully combating Schmutz and Schund. ${ }^{58}$ While cases of juvenile delinquency were frequently related to mimicry of actions depicted in film or print, social democrats admonished the public to keep in mind that the children involved were most often the products of single parent families or had parents who were unemployed, physically challenged, alcoholics, or otherwise socially marginalized. ${ }^{59}$

The government took notice of the agitation in favor of changing the law, but instead of a revision along the lines of the SPÖ's demands Education Minister Heinrich Drimmel, Hurdes's successor, successfully introduced a conservative amendment to the legislation. The changes extended the upper age limit for protection from Schmutz and Schund from sixteen to eighteen, and the government made a firm commitment to work with youth associations and pedagogical groups to provide comprehensive cultural alternatives to unsavory publications. ${ }^{60}$ Any effort to restrict the influx of comic books from abroad was rejected as economically and politically unfeasible by the Ministry of Trade and Reconstruction; increased liberalization of book imports from the OEEC states made it impossible to ban or even increase the tax on Schundliteratur. These publications fell under a broader tariff category for literature that protected them from special duties; the Center for 
Import and Export was entitled to exact merely the standard 5.25 percent equalization tax. ${ }^{61}$ The creation of a special tariff category for Schundliteratur would trigger retaliatory measures by the other OEEC states, which would rebound to Austria's disadvantage. ${ }^{62}$ In short, no action was taken to hinder importation of pulp fiction. In the end, SPÖ opponents of the final, amended version of the Schmutz und Schund legislation found themselves caught between their position as advocates of press freedoms and their recommendation of import restrictions, and between their rejection of conservative paternalism and their own protectionist pedagogical conceptions.

\section{Conclusion}

Given the overwhelming desire on the part of Austrians to establish a peaceful, independent existence after the Second World War, in contrast with Lager-based rivalry and pro-Anschluss sentiment between the world wars, the postwar years presented opportunities to Austrian politicians, pedagogues, and social engineers that were every bit as vital to the stability of the Second Republic as similar initiatives were during the First Republic. ${ }^{63}$ Curiously, though, historians of the Second Republic have largely ignored the importance of educational strategies, cultural initiatives, enduring political and religious values, and consumption patterns that contributed to political socialization and the rethinking of cultivating a state identity for both Austrian children and adults after $1945 .{ }^{64}$

Experts in both social democratic and Catholic-conservative circles feared the influence that Schmutz and Schund would have upon respect for the "classical" Austrian literary inheritance (much of which was the work of German novelists, essayists, dramatists, and poets) and the ability to cultivate an audience for future Belletristik, albeit for very different reasons and with quite different ends in mind. As I have endeavored to show, consensus concerning the precise nature of intervention against pornographic and pulp literature was complicated by the fact that politicians and education experts from the social democratic and Catholicconservative camps could not agree conclusively upon a comprehensive definition for either genre. Even though representatives of both Lager acknowledged the importance of governmental action against allegedly harmful printed matter, film, and cabaret, ideological concerns precluded the establishment of the sort of unified stance necessary for consistent, purposeful enforcement of the compromise law against Schmutz and Schund. Each party deemed the successful encoding of constructive, indeed instructive principles through leisure-time activities as essential for the reproduction of these principles over subsequent generations, thereby contributing to a sense of Austrian identity characterized overwhelmingly by either social democratic or Catholic-conservative values. Considered in this light, Austrian authorities regarded children's socialization as ultimately no less significant for the future stability of Austrian society than they did economic reconstruction, denazification, or negotiating the end of four-power occupation. 
Extracurricular youth legislation was intended, then, to function as a momentous step in creating - or redefining-identity. Quite simply, the Lager that had the greater influence over youth had the potential to enjoy greater power in determining cultural norms for subsequent generations. Given that youth knew nothing but intolerant nationalism and war on the one hand, and civil war and vicious political intolerance on the other between 1914 and 1945, educators faced an extraordinarily difficult task in children's (re-)socialization.

The classroom was not the only venue in which public institutions, private organizations, political parties and pedagogues sought to develop a new, enduring sense of Austrianness. Many educational experts, almost all of them social democrats, insisted that in the interests of the moral and intellectual development of Austrian children and of future social stability, children should have access to reading material that would encourage them to become well-educated Austrians committed to peace, social justice at home and abroad, and international cooperation. Leading Catholic-conservative spokespersons, for their part, faced these challenges with a preoccupation vis-à-vis progressive threats to a traditional, religiously based conception of moral safeguards through an emphasis upon censorship. The only parcel of common ground upon which these divergent interests could meet was a pervasive anxiety over an ostensible debasement of culture. This was a concern rooted in the late nineteenth- and early twentieth-century circumstances of modernization, the widespread preoccupation with material security after World War II, and a distinct undercurrent of critical disdain towards American-style popular, consumer-oriented culture, expressed as early as the 1920s (albeit differently) in both social democratic and Catholic-conservative circles. In the end, as. the historian Siegried Mattl has noted, two, parallel developments are discernible in Austria during the course of the 1950s: a rather progressive form of social and economic modernization and an ultimately conservative response to this modernization in cultural politics. ${ }^{65}$ A significant factor in this outcome was undoubtedly the fact that, during the late 1940s and early 1950s, the SPÖ leadership found it expedient to sacrifice advancement in the latter realm for progress in the former. Social democratic youth activists and their party spokespeople would not really be in the position to breathe a measure of new life into cultural policy until after 1968 , and even then only with mixed results.

Nonetheless, debate over the initiative against Schmutz and Schund breached newly established norms in the consensus and compromise-oriented political cultural of the Second Republic. Matters of cultural policy that could not be easy settled through coalition and the institutions of social partnership proved difficult for the ÖVP and the SPÖ to negotiate, for they challenged the very principles upon which these organizations rested, the principles for which many of their constituents had sacrificed and suffered between 1918 and 1945 and were unwilling to jettison with the creation of the Second Republic. Protected by the status of "the first victim of Nazi aggression" during the years of occupation, both the formal and neo- 
corporatist shadow government successfully concentrated Austrians' energies upon the work of material reconstruction, sheltering many of them from confrontation with their civil war and Nazi-era experiences-a dynamic characterized as "tabooization" by Anton Pelinka and Erika Weinzierl. Controversies over the politics of playtime, historical and civics education, the place of the Roman Catholic Church in postwar Austrian society, and other challenges in the broad realm of the politics of culture threatened the meta-discourse of cooperation and consensus fundamentally, if only for brief moments, by forcing Austrians to recognize the cracks in the fresh, whitewashed wall that separated the Second Republic from its past, that belied the notion of a Stunde Null. The question of what Austria-what Austrians - would, or had, become remained contested ground, for the future's contours were not, and could not be agreed upon conclusively. ${ }^{66}$ In the recent short several years encompassing the Waldheim controversy, on-again/off-again popular support for European Union membership, and the lackluster 1000 Jahre Österreich celebration, it would appear that the question is still some way from even provisional denouement.

\footnotetext{
${ }^{1}$ See, for example, Jonas Frykman and Orvar Löfgren, Culture Builders: A Historical Anthropology of Middle-Class Life (New Brunswick, N.J., 1987); Michael Mitterauer, Sozialgeschichte der Jugend (Frankfurt/Main, 1986); Detlef Peukert, Grenzen der Sozialdisziplinierung: Aufstieg und Krise der deutschen Jugendfürsorge von 1878 bis 1932 (Cologne, 1986), 167-68. The literature on education in Imperial Germany and the later Habsburg Empire is a particularly vast one, and it is beyond the scope of this essay to reference it comprehensively. Among the noteworthy contributions to the historiography of children's education, however, are: James C. Albisetti, Secondary School Reform in Imperial Germany (Princeton, 1983); Helmut Engelbrecht, Geschichte des österreichischen Bildungswesens: Erziehung und Unterricht aufdem Boden Österreichs, vols. I-IV, (Vienna, 1988); Günter Erning, Karl Neumann, and Jürgen Reyer, ed., Geschichte des Kindergartens: Entstehung und Entwicklung der öffentlichen Kleinkindererziehung in Deutschland, vol. III (Freiburg, 1987); and Marjorie Lamberti, State, Society, and the Elementary School in Imperial Germany (New York/Oxford, 1989).

${ }^{2}$ Detlef Peukert, The Weimar Republic: The Crisis of Classical Modernity (New York, 1989), 164-90; Karin M. Schmidlechner, "Youth Culture in the 1950s," Contemporary Austrian Studies 3 (1995): 116-37; Ralph Willett, The Americanization of Germany, 1945-1949 (London, 1989); Reinhold Wagnleitner, Coca-Colonization and the Cold War: The Cultural Mission of the United States in Austria after the Second World War (Chapel Hill, 1994), esp. 166-274.
} 
${ }^{3}$ Margaret F. Stieg, "The 1926 German Law to Protect Youth Against Trash and Dirt: Moral Protectionism in a Democracy," Central European History 23 (1990): 22-56; Georg Jäger, "Der Kampf gegen Schmutz und Schund: Die Reaktion der gebildeten auf die Unterhaltungsindustrie," Archiv für Geschichte des Buchwesens 31 (1988): 163-91; Luke Springman, "Poisoned Hearts, Diseased Minds, and American Pimps: The Language of Censorship in the Schmutz und Schund Debates," The German Quarterly 68 (1995): 408-29. ${ }^{4}$ Notable exceptions here are Peukert, The Weimar Republic; Alfred Pfoser, Literatur und Austromarxismus (Vienna, 1980); Peter D. Stachura, "Das Dritte Reich und die Jugenderziehung: Die Rolle der Hitlerjugend 1933-1939," in Karl Dietrich Bracher, Manfred Funke, and Hans-Adolf Jacobsen, ed., Nationalsozialistische Diktatur 1933-1945-Eine Bilanz (Bonn, 1986), 224-44.

${ }^{5}$ The literature on the governmental and semi-public institutions of Austrian consensusbuilding and cooperative government is a vast one. See, for example, Peter Katzenstein, Corporatism and Change: Austria, Switzerland, and the Politics of Industry (Ithaca, 1984); Manfried Rauchensteiner,Die Zwei: Die grosse Koalition in Österreich, 1945-1966(Vienna, 1987); Alfred Klose, Machtstrukturen in Österreich (Vienna, 1987); Herbert Dachs et al., eds., Handbuch des politischen System Österreichs, 2d ed. (Vienna, 1992), 335-415; and Emmerich Tálos and Bernhard Kittel, "Sozialpartnerschaft: Zur Konstituierung einer Grundsäule der Zweiten Republik" in Reinhard Sieder, et al., eds., Österreich, 1945-1955: Gesellschaft, Politik, Kultur (Vienna, 1995), 107-121. For an overview of social policy during the 1950s, see Ernst Hanisch Der lange Schatten des Staates: Österreichische Gesellschaftsgeschichte im 20. Jahrhundert (Vienna, 1994), 407-15.

${ }^{6}$ Manfried Rauchensteiner, "Gereglte Verhältnisse? Innenpolitische Mavövierräume und ihre Spielregeln," in Inventur 1945/55: Österreich im ersten Jahrzehnt der Zweiten Republik, ed. Wolfgang Kos and Georg Rigele (Vienna, 1996), 268-86.

${ }^{7}$ On the significance of the civil war in the political culture of the Second Republic, see Elisabeth Klamper, “'Ein einig Volk von Brüdern': Vergessen und Erinnern im Zeichen des Bürgerkrieges," Zeitgeschichte 24 (1997): 170-85.

${ }^{8}$ See Anton Pelina and Erika Weinzierl, ed., Das grosse Tabu: Österreichs Umgang mit seiner Vergangenheit (Vienna, 1987).

${ }^{9}$ See, for example, Matthew Paul Berg "Between Kulturkampf and Vergangenheitsbewältigung: The SPÖ, the Roman Catholic Church, and the Problem of Reconciliation" and Maria Mesner, "Die 'Neugestaltung des Ehe- und Familienrechts': Re-Definitions potentiale im Geschlechtsverhältnis der Aufbau-Zeit," Zeitgeschichte 24 (1997): 147-69 and 186-210, respectively.

${ }^{10}$ Detlef Peukert's analysis of Weimar Germany is equally relevant for Austria after 1945: "The principle goal of pedagogic care had been to bring order, stability, diligence, and a modest, but confident perspective on life into the circumstances of chaos and neglect perceived among the marginalized underclass. In order to give a certain measure of credibility and immediacy to such an initiative, the points of departure for a relatively confident perspective on life had to be delineated perceptibly for young people in [their] social reality as well." See Peukert, The Weimar Republic, 167-68. 
"On social democratic cultural work during the interwar years see Alfred Georg Frei, Rotes Wien: Austromarxismus und Arbeiterkultur. Sozialdemokratische Wohnungs- und Kommunalpolitik, 1919-1934 (Berlin, 1984); Helmut Gruber, Red Vienna: Experiment in Working-Class Culture, 1919-1934(New York/Oxford, 1991); Bela Rásky, Arbeiterfesttage: Die Fest- und Feiernkultur der sozialdemokratischen Bewegung in der Ersten Republik (Vienna, 1992); and Josef Weidenholzer, Auf dem Weg zum "Neuen Menschen": Bildungsund Kulturarbeit der österreichischen Sozialdemokratie in der Ersten Republik (Vienna, 1992). The attention addressed to leisure time activities after 1945 has only somewhat recently become more pronounced. In the German context see Axel Schildt, “ 'Mach mal Pause!' FreieZeit, Freizeitverhalten und Freizeit-Diskurse in der westdeutschen WiederaufbauGesellschaft der 1950er Jahre," Archiv für Sozialgeschichte 33 (1993): 357-406; for Austria, see Wagnleitner, Coca-Colonization.

${ }^{12}$ Pfoser, Literatur und Austromarxismus, 127.

${ }^{13}$ Ibid., 130-44. See also Weidenholzer, Auf dem Weg zum "Neuen Menschen," chs. 5-6 passim. On patrons' borrowing preferences see Gruber, Red Vienna, 95.

${ }^{14} Z$ o., "Gegen Schmutz und Schund," Die Zukunft (1947/3): 95.

${ }^{15} \mathrm{ÖStA} / \mathrm{AdR}, \mathrm{BKA} / \mathrm{VD}$ 64.149-2a/1948. "Nr. 14 der Beilagen zum stenographischen Protokoll des Salzburger Landtages, Vorlage der Landesregierung eines Gesetz zum Schutze der Jugend."

${ }^{16}$ ÖStA/AdR, BMU 10.762-III/10/1948, Heiterer (BKA) to the Amt der Salzburger Landesregierung, 4 August 1947, and to the Amt der steiermärkischen Landesregierung, 14 October 1947.

${ }^{17 O ̈ S t A / A d R, ~ B M U ~ 33.432-I I I / 10 / 1948: ~ B K A / V D ~ 58.376-2 a / 1947 ; ~ B M U ~ 6.487-I I I / 10 / ~}$ 1948; and BMJ 11.199/48. See also ÖStA/AdR, BMU 34.336-III/10/1948 regarding Interior Minister Oskar Helmer's (SPÖ) refusal to support a proposal advanced by the ÖVP's Nationalrat deputy from Linz, Franz Brandl (BMI 73.218-4/1948). Brandl sought to dredge up a measure against Schmutz und Schund promulgated during the years of the Vaterländische Front, the clerical fascist regime of 1934-1938. Helmer argued that it was preposterous to consider enforcing a law drafted during a period in which legal, political, and social circumstances differed so dramatically. See also ÖStA/AR, BMU 34.336-III/10/1948 for the Gedächtnisprotokoll of the interministerial at which time it was decided that a suitable law would have to be drafted from scratch.

${ }^{18}$ ÖStA/AdR, BMU 33.432-III/10/1948. Justice Minister Gerö, 21 April 1948, to all Oberstaatsanwaltschaften and Staatsanwaltschaften (BMJ Zl. 11.323/1948).

${ }^{19}$ Ibid.

${ }^{20} \mathrm{ÖStA} / \mathrm{AdR}, \mathrm{BMU} 33.432-\mathrm{III} / 10 / 1948$. Zechner to Federal Chancellor Figl, 19 March 1948. ${ }^{21}$ ÖStA/AdR, BMU 35.749-III/1 0/1948; "Steuer auf Schmutz und Schund!” Der Volksbote, 3 June 1948.

${ }^{22}$ Ibid.

${ }^{23}$ ÖStA/AdR, BMU 35.749-III/10/1948. See letter of Carl Blumau, Zeitungs- und Zeitschriften Zentrale, Innsbruck of 4 June 1948 to BMU. "It is indeed grotesque," Blumau complained, "if one imagines that a Landesschulrat, who is responsible first and foremost for tasks related to the education of [our] youth, should have the chance to be able to prescribe a censorship measure for me and every other person who is an adult and not intellectually impaired." 
${ }^{24}$ ÖStA/AdR, BMU 9.574-III/10/1949. On the response to the outline, see Hurdes to Figl on the nature of the outline, in ÖStA/AdR, BMU 14.962-III/10/1949.

${ }^{25}$ ÖStA/AdR, BMU 11.520-III/10/1949: 7. "Gedächtnisprotokoll einer interministeriellen Besprechung über den Entwurf eines Bundesgesetzes zum Schutz der Jugend gegen Schmutz und Schund," comment of BMU Ministerrat Haustein, 7 March 1949.

${ }^{26}$ Theodor Körner, the Socialist mayor of Vienna, noted that a central law for all the Bundesländer could not account for the regional differences in the mentality of the Austrian population. Reported in "Stellungnahmen zum ho. Entwurf eines Bundesgesetzes über den Schutz der Jugend gegen Schmutz und Schund," ÖStA/AdR, BMU 41.150-V/10/1949, "Stellungnahmen," 16.

${ }^{27}$ Ibid., 4. The Bishops of Linz and of Salzburg concurred with this opinion; ibid., 7.

${ }^{28}$ ÖstA/AdR, BMU 41.150-V/10/1949, "Stellungnahmen," 22. This suggestion found favor with Justice Minister Gerö, and eventually made its way into the final draft.

29،"Stellungnahme der Interessengemeinschaft des katholischen Buchhandels in Österreich." Ibid., 21.

${ }^{30}$ Ibid., BMJ Sektionsrat Handler to BMU, 17 October 1949: 1-2.

${ }^{31}$ Ibid., 46. This suggestion was not adopted in the draft adopted in March 1950.

${ }^{32}$ ÖStA/AdR, BMU 33.670-III/10/1949. "Entwurf zu einem Bundesgesetz über den Schutz der Jugend gegen Schmutz und Schund," $§ 16$, Abs. (1).

${ }^{33}$ Ibid.; Sektionsrat Handler to BMU, 10.

${ }^{34}$ Ibid., 4.

${ }^{35}$ See ÖStA/AdR, BMU 488-III/10/1950 for Justice Ministry draft.

${ }^{36}$ Oscar Pollak, "Schund und Schmutz-und Schutz," Die Zukunft (1950/3): 71.

${ }^{37}$ Ibid.

${ }^{38}$ Ibid.

${ }^{39}$ Ibid., 72.

${ }^{40}$ Ibid., 72-73.

${ }^{41}$ See Ingrid Bauer, "Von den Tugenden der Weiblichkeit: Zur geschlechtsspezifischen Arbeitsteilung in der politischen Kultur," in Österreich in den Fünfzigern, Thomas Albrich, Klaus Eisterer, Michael Gehler, and Rolf Steininger, eds., (Innsbruck, 1995), 35-52, as well as Erika Thurner "Die stabile Innenseite der Politik: Geschlechterrollen im Spiel gesellschaftlicher Anforderungen," ibid., 53-66.

${ }^{42}$ While one could, indeed, speak abstractly of cultural norms, Leopold Zechner charged, "judgement over what is artistically worthwhile and what is worthless, over that which is reputed to be ethical and, indeed, unethical is very different in each individual case, and is extraordinarily dependent upon taste, level of education, as well as upon Weltanschauung. There will always be a considerable difference between the opinions of nuns, elderly Institutsvorsteherinnen, and young, broad-minded people, between the opinions of those who live in quiet seclusion and those who exist in the middle of a large city's hustle-bustle." Zechner, Sten.Prot.NR, VI. G.P., 19th Session, 15 March 1950, 569.

${ }^{43}$ Ibid.

${ }^{44}$ See Strasser and Ernst Fischer, Sten.Prot.NR, VI. G.P., 23rd Session, 31 March 1950, 864 and 858 , respectively. 


\footnotetext{
${ }^{45}$ Strasser, ibid., 869. Strasser referred to May sarcastically as a "beloved paragon of Christian virtue."

${ }^{46}$ Ibid., 866. The Justice Ministry outline proposed to punish those engaged in the "distribution, display or pictorial representation" of works that "awakened, lead astray, or stimulated sexual longing" in children under sixteen with a fine of ÖS 3,000 or one month in prison. "Erläuternde Bemerkungen zum Bundesgesetz vom..., 1950 über die Bekämpfung unzüchtiger Veröffentlichungen und den Schutz der Jugend gegen sittliche Gefährdung," BMJ Zl. 10.364/1950, in ÖStA/AdR, BMU 10.863-III/10/1950, 5.

${ }^{47} \mathrm{ÖSt} / \mathrm{AdR}, \mathrm{BKA} 5.937-\mathrm{III} / \mathrm{Pol} / 1950$. J. C. Dutheil, Chairman of the Executive Committee of the Allied Commission for Austria (SECA 50/55).

${ }^{48}$ The preoccupation with smut was heightened when "sexually" libertine rock 'n' roll music reached Austria in the mid 1950s. "According to the opinion of an Austrian critic, this Shaking and Squirming would lead even an objective viewer to understand that this was only a dancing version of highly explicit acts-and that was also thoroughly intended." In Wagnleitner, Coca-Colonization, 288.

${ }^{49}$ Anton Parfuss, VGA/PAdSPÖ-Radiovorträge.

${ }^{50}$ Richard Bamberger, "Auch wir haben Schundbücher gelesen. . .," Arbeiter-Zeitung, 9 February 1955.

${ }^{51}$ For Bamberger and other Socialist intellectuals, the discrepancy between ÖVP fears and socioeconomic realities pointed out all the more vividly how an exploitative capitalist business spirit had come to regard children's free time as an easy market for the new "pleasure industry" that manufactured and sold toys, books, and audio-visual entertainment of dubious pedagogical value. Ibid.

${ }^{52}$ Ibid.

${ }^{53}$ See Anton Tesarek, cited in Helmut Butterweck, "Gift in bunten Heften: Eine Flụt von 'Crime'- und 'Horror' Comics überschwemmt den österreichischen Markt," Weltpresse, 5 October 1955. See also the interview with Richard Bamberger, in "100 Millionen Schilling jährlich für Schmutz und Schund,” Der Abend, 21 January 1956.

${ }^{54}$ Butterweck, "Gift in bunten Heften."

${ }^{55}$ Wagnleitner, Coca-Colonization, 103-4.

${ }^{56}$ Ibid.

57"Wir müssen die Jugend schützen: Tagung 'Buch und Bild' beschäftigt sich mit dem 'Schmutz und Schund' Problem,” Wiener Zeitung, 22 September 1955.

${ }^{58}$ Anton Zimmerwald, "Und immer wieder gegen Schmutz und Schund," Sozialistische Erziehung (1957/2): 44.

59،"Ist nur das Kino schuld?" Arbeiter-Zeitung, 31 January 1956.

${ }^{60}$ ÖStA/AdR, BMU 83.113-III/10/1958; ÖStA/AdR, BMU 101.879-III/10/1958; ÖStA/ AdR, BMU 34.III/10/1959.

${ }^{61} \mathrm{ÖStA} / \mathrm{AdR}, \mathrm{BMU}$ 38.350-III/11/1955; ÖStA/AdR-BMHW 205.647-IV/28/1955.

${ }^{62}$ Ibid.

${ }^{63}$ See again Gruber, Red Vienna; Frei, Rotes Wien; Wolfgang Maderthaner, "Kommunalpolitik im Roten Wien: Ein Literaturbericht," Archiv für Sozialgeschichte 25 (1985): 240-50.
} 
${ }^{64}$ Among the most notable exceptions to this pattern of neglect are Walter Göhring, Bildung in Freiheit: Die Erwachsenenbildung in Österreich nach 1945 (Vienna, 1983). Historians have directed considerable attention towards efforts to refashion German identity through pedagogical, cultural, and economic development in the years after 1945, and this body of Germany-focused literature is enormous. See, for example, Hans-Dieter Schmid, "Die Entwicklung des Geschichtsunterrichts in der SBZ/DDR," in Gesellschaft-StaatGeschichtsunterricht: Beiträge zu einer Geschichte der Geschichtsdidaktik und des Geschichtsunterrichts von 1500-1980, Klaus Bergmann and Gerhard Schneider, eds., (Düsseldorf, 1982), 313-48; Ulrich Mayer, "Geschichtsdidaktik und Geschichtsunterricht in der Nachkriegszeit (1945-1963)," ibid., 349-80; Joachim Rohlfes, "Geschichte und Geschichtsdidaktik 1953 bis 1969," ibid., 381-414; Nicholas Pronay and Keith M. Wilson, eds., The Political Re-education of Germany and her Allies after World War II (Totowa, N.J., 1985); James F. Tent, Mission on the Rhine: Reeducation and Denazification in AmericanOccupied Germany (Chicago, 1982).

${ }^{65}$ Siegfried Mattl, "Die regulierte Demokratie: Eine kritische Bilanz der sozialen System in Österreich," in Inventur 45/55, 349-50.

${ }^{66}$ See Pelinka and Weinzierl, eds., Das grosse Tabu, particularly Hermann Langbein, "Darf man vergessen?" 8-16; Nadine Hauer, "NS-Trauma und kein Ende," 28-41; Anton Pelinka, "Der verdrängte Bürgerkrieg," esp. 149. See also Gerhard Botz and Gerald Sprengnagel eds., Kontroversen um Österreichs Zeitgeschichte: Verdrängte Vergangenheit, Österreich-Identität, Waldheim und die Historiker (Frankfurt/Main, 1994). Since the later 1980s reactions to the work of Alfred Hrdlicka or the dramaturgy of Thomas Bernhard, the emotions stirred by the Waldheim presidency, or Jörg Haider's comments represent an opening of a Pandora's Box, the violation of this taboo. 